\title{
Cough threshold to citric acid in diabetic patients with and without autonomic neuropathy
}

\author{
L G VIANNA, S G GILBEY, N C BARNES, R J C GUY, B J GRAY
}

\author{
From the Department of Thoracic Medicine and the Diabetic Department, King's College School of Medicine \\ and Dentistry, London
}

\begin{abstract}
The cough reflex has been investigated in insulin dependent diabetic patients with and without autonomic neuropathy. The cough response to inhaled citric acid was determined in eight patients with diabetes who had severe autonomic neuropathy and compared with that in 10 who had no evidence of neuropathy. The patients with autonomic neuropathy had a higher median threshold for the cough response to citric acid (median 50\%, range $20->100 \%$ ) than non-neuropathic control patients (median 10\%, range $2-20 \%$ ). These results suggest that vagal innervation of the bronchial tree is damaged by diabetic autonomic neuropathy.
\end{abstract}

\section{Introduction}

Diabetic autonomic neuropathy is responsible for widespread abnormalities in affected patients. Damage to the vagus nerve is well documented and causes impairment of cardiovascular reflexes and gastric emptying. ${ }^{1}$ Relatively little is known about impairment of the respiratory system. Diabetic patients with autonomic neuropathy have been shown to have a decreased bronchodilator response to inhaled anticholinergic drugs despite normal resting airway calibre, ${ }^{2}$ a diminished bronchial response to eucapnic hyperventilation of cold air, ${ }^{3}$ but a normal bronchoconstrictor response to inhaled histamine. ${ }^{4}$

Determining the threshold for the response to inhaled citric acid is a simple and reproducible method of quantifying the cough reflex. ${ }^{56}$ We measured the cough threshold for citric acid in a group of diabetic patients with and without severe autonomic neuropathy. The afferent arc bf the cough reflex is vagally mediated, but has not been previously investigated in subjects with diabetic autonomic neuropathy.

\section{Methods}

SUBJECTS

We studied two groups of non-smoking insulin dependent diabetic patients (table). The first consisted of

Address for reprint requests: Dr B J Gray, Department of Thoracic Medicine, King's College School of Medicine and Dentistry, London SE5 9PJ.

Accepted 28 April 1988 eight patients (one male, seven female), mean age 37 (range 24-52) years, with known severe symptomatic autonomic neuropathy (heart rate variability less than 10 beats/minute). ${ }^{7}$ Seven had at least one autonomic symptom and one had Charcot neuroarthropathy in addition to documented evidence of severe somatic and autonomic neuropathy. All had retinopathy (six proliferative, two background) and four had persistent proteinuria as shown by Albustix testing. The second group consisted of 10 patients (three male, seven female), mean age 36 (range 22-57) years, with intact ankle jerks and no evidence of sensory loss or of autonomic neuropathy; none of these patients had retinopathy or proteinuria.

No patient had a history of respiratory disease or atopy and none had had an upper respiratory tract infection within six weeks of being tested. All were non-smokers. Forced expiratory volume in one second $\left(\mathrm{FEV}_{1}\right)$ was within the normal predicted range ${ }^{\mathrm{x}}$ in all subjects. To avoid the effects of suggestion, subjects were told that they would be inhaling a harmless substance and that an effect would be observed, but they were not told that cough was being assessed. All subjects gave informed consent, and the study was approved by the hospital ethical committee.

\section{AUTONOMIC FUNCTION}

Symptoms of autonomic neuropathy were defined as follows:

gustatory sweating-facial sweating precipitated by eating specific foods;

diabetic diarrhoea - intermittent diarrhoea with or without incontinence and with no evidence of other gastrointestinal disease; 
Clinical details and results of autonomic function tests in the diabetic patients studied

\begin{tabular}{|c|c|c|c|c|c|c|c|c|c|}
\hline \multirow{2}{*}{$\begin{array}{l}\text { Case } \\
\text { No }\end{array}$} & \multirow{2}{*}{$\begin{array}{l}\text { Age } \\
(y)\end{array}$} & \multirow{2}{*}{$\begin{array}{l}\text { Duration of } \\
\text { diabetes } \\
(y)\end{array}$} & \multirow{2}{*}{$\begin{array}{l}\text { Autonomic } \\
\text { symptoms }\end{array}$} & \multirow{2}{*}{$\begin{array}{l}\text { Resting } \\
\text { heart rate } \\
\text { lying } \\
\text { (beats } / \mathrm{min} \text { ) }\end{array}$} & \multirow{2}{*}{$\begin{array}{l}\text { Increase in } \\
\text { heart rate } \\
\text { on standing } \\
\text { (beats } / \text { min) }\end{array}$} & \multirow{2}{*}{$\begin{array}{l}\text { Heart rate } \\
\text { variation } \\
\text { (beats } / \text { min) }\end{array}$} & \multirow{2}{*}{$\begin{array}{l}\text { Valsalva } \\
\text { ratio }\end{array}$} & \multicolumn{2}{|c|}{ Blood pressure $(\mathrm{mm} \mathrm{Hg})$} \\
\hline & & & & & & & & Lying & Standing \\
\hline \multicolumn{10}{|c|}{ WITH NEUROPATHY } \\
\hline 1 & 52 & 41 & DD & 98 & 6 & 2 & $1 \cdot 1$ & $166 / 85$ & $139 / 75$ \\
\hline 2 & 39 & 27 & DD & 105 & 12 & 4 & $1 \cdot 0$ & $112 / 80$ & $117 / 76$ \\
\hline 3 & 31 & 26 & GS DD & 107 & 16 & 4 & $1 \cdot 1$ & $135 / 94$ & $116 / 83$ \\
\hline 4 & 39 & 17 & $\begin{array}{l}\text { GS }{ }_{\text {BP }}^{\text {GP }} \text { PH } \\
\text { PP }\end{array}$ & 96 & 8 & 4 & $1 \cdot 0$ & $149 / 95$ & $95 / 76$ \\
\hline 5 & 29 & 19 & Charcot foot & 83 & 10 & 7 & $1 \cdot 1$ & $149 / 89$ & $138 / 90$ \\
\hline 6 & 24 & 21 & DP PH & 92 & 4 & 3 & $1 \cdot 0$ & $138 / 80$ & $100 / 60$ \\
\hline 7 & 39 & 27 & GS DD PH & 102 & 8 & 2 & $1 \cdot 0$ & $132 / 90$ & $72 / 53$ \\
\hline 8 & 43 & 24 & DD GS & 108 & 6 & 6 & $1 \cdot 0$ & $120 / 83$ & $93 / 68$ \\
\hline Mean & 37 & 25 & & 99 & $8 \cdot 8$ & 4 & $1 \cdot 03$ & & \\
\hline \multicolumn{10}{|c|}{ WITHOUT NEUROPATHY $(n=10)$} \\
\hline Mean & 36 & & & 69 & 25 & 23 & $1 \cdot 6$ & & \\
\hline Range & $22-57$ & $10-31$ & & $65-100$ & $12-36$ & $16-35$ & $1.4-1.9$ & & \\
\hline
\end{tabular}

GS—gustatory sweating; DD—diabetic diarrhoea; PH-postural hypotension; BP—bladder paresis; GP_gastroparesis.

postural hypotension - symptoms of hypotension on standing with a postural fall in systolic blood pressure of $30 \mathrm{mmHg}$ or more;

gastroparesis - episodes of recurrent vomiting with gastric emptying delayed in barium investigations and with no evidence of other gastric disease;

bladder paresis - symptoms of impaired bladder emptying with a residual urine volume of over $70 \mathrm{ml}$ determined by ultrasound investigation and no evidence of mechanical obstruction.

Autonomic function tests were performed after five minutes' rest in the supine position. Heart rate was monitored with a Lectromed ratemeter, MX2P amplifier, and MX212 chart recorder. The response of heart rate to standing and its variation during deep breathing at six breaths a minute were recorded. ${ }^{7}$ The Valsalva ratio was recorded as the ratio of the maximum tachycardia to the maximum bradycardia during a standard Valsalva manoeuvre. ${ }^{9}$ Blood pressure was measured supine and at 60 second intervals for at least three minutes after standing up with a Critikon Dinamap automatic blood pressure monitor; the lowest systolic pressure recorded was used to calculate the extent of postural hypotension.

\section{COUGH THRESHOLD MEASUREMENT}

Nebulised citric acid was administered at concentrations of $1 \%, 2 \%, 5 \%, 10 \%, 20 \%, 50 \%$, and $100 \%$ (weight by volume) double blind and in random order. Subjects took three timed vital capacity breaths of five seconds' duration, starting at residual volume and with a gap of 15 seconds between inhalations. Any coughs during inhalation and for the next five minutes were counted. A further concentration of citric acid was then inhaled. Aerosol for inhalation was generated by a Wright nebuliser containing $4 \mathrm{ml}$ of test solution and driven by compressed air at a flow rate of 7 litres/min. All studies were performed in the early afternoon by an investigator (LV) unaware of the ${ }^{\infty}$ neuropathic condition of the patient. The cough threshold was defined as the lowest concentration of citric acid provoking more than one cough.

Statistical analysis was by Wilcoxon's rank sum test.

\section{Results}

The median cough threshold concentrations in the non-neuropathic group was $10 \%$ citric acid (range $2-20 \%$ ) and the geometric mean value was $7 \cdot 4 \%$

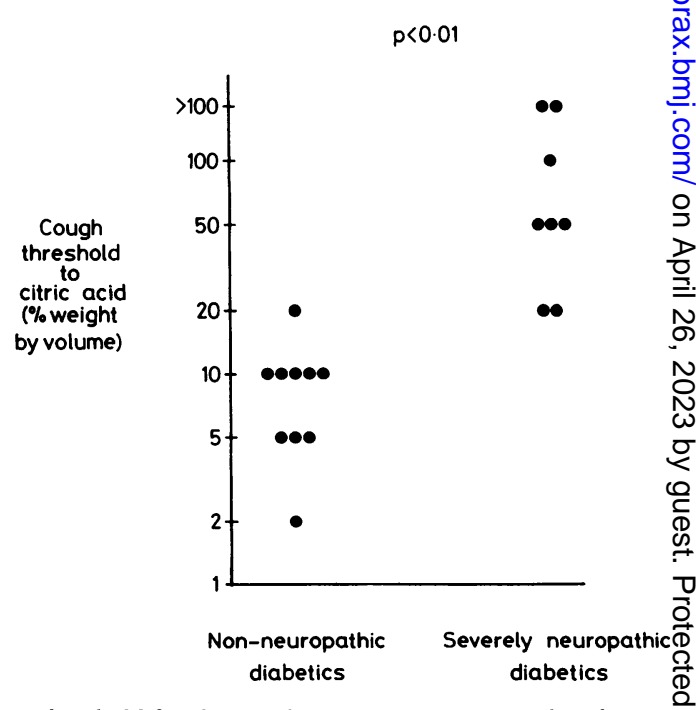

Threshold for the cough response to citric acid in the two groups studied. 
citric acid. The geometric mean cough threshold concentration in the neuropathic group was significantly higher at $51.6 \%$ citric acid ( $\mathrm{p}<0.01$ ). Individual results in this group ranged from $20 \%$ (two subjects), $50 \%$ (three subjects), and $100 \%$ (one subject) to unrecordable in two subjects who failed to cough with $100 \%$ citric acid (figure).

\section{Discussion}

We have shown that cough reflexes are diminished (and sometimes absent) in patients with severe diabetic autonomic neuropathy when compared with control patients with uncomplicated diabetes.

Determining the cough response to nebulised citric acid solutions by a constant method provides a simple and reproducible method of measuring cough threshold. ${ }^{5}$ In this study we gave increasing doses of citric acid up to $100 \%$ in random order, using three vital capacity breaths, in an attempt to ensure that a clear cough threshold was established whenever possible. Previous methods have sometimes failed to establish a threshold in all subjects. Three submaximal inspirations of up to $50 \%$ citric acid established a cough threshold in four out of five subjects, ${ }^{5}$ and a single timed vital capacity inhalation of increasing concentrations of citric acid aerosol in a non-randomised fashion induced cough in only six out of eight normal subjects. ${ }^{10}$ The maximum concentration of citric acid administered by Pounsford et $a l^{11}$ was relatively low at $32 \%$, so their results are not directly comparable to those from our control group of nonneuropathic diabetic patients.

All the neuropathic patients in this study had evidence of vagal neuropathy from cardiovascular testing. Animal studies have shown that the cough reflex is stimulated by rapidly adapting receptors in the larynx and bronchial tree with afferent fibres in the vagus nerve. ${ }^{112}$ These receptors, which are touch receptors in the larger airways" and "irritant receptors" in smaller airways, ${ }^{13}$ are thought to be stimulated and sensitised by bronchoconstriction, although this may be the case only when airway calibre is changing rapidly. ${ }^{10}$ Thus, although resting airway vagal tone is decreased in diabetic patients with autonomic neuropathy, ${ }^{2}$ this is unlikely to account for the increased cough threshold. Their difference from non-neuropathic diabetic controls suggests that the raised threshold is unlikely to be due to a non-specific effect of diabetes on pulmonary receptors.

Previous work has shown that the bronchoconstrictor response to cold air is impaired in patients with diabetic autonomic neuropathy ${ }^{3}$ and by implication the cold air response in normal, non-asthmatic subjects is vagally mediated. The response to inhaled histamine in diabetic autonomic neuropathy, however, is normal, indicating that the bronchial smooth muscle reacts normally to a direct stimulus. ${ }^{4}$
Our study suggests that vagal afferent fibres innervating the bronchial tree and mediating the cough reflex are affected in diabetic autonomic neuropathy. Although respiratory symptoms are not a feature of diabetic autonomic neuropathy, impaired respiratory reflexes may have important clinical consequences, not least in provoking unexpected cardiorespiratory arrest in diabetic patients with autonomic neuropathy. ${ }^{14}$

We wish to thank Drs P J Watkins and J Costello for their advice and help with the study and their permission to study patients under their care; Dr R W Heaton for his help with the design of the method we used; and Miss K Jones, who typed the manuscript.

\section{References}

1 Watkins PJ, Edmonds ME. Clinical presentation of diabetic autonomic failure. In: Bannister R, ed. Autonomic failure. Oxford: Blackwell Scientific Publications, 1983: 337-70.

2 Douglas NJ, Campbell IW, Ewing DJ, Clarke BF, Flenley DC. Reduced airway vagal tone in diabetic patients with autonomic neuropathy. Clin Sci 1981;61:581-4.

3 Heaton RW, Guy RJC, Gray BJ, Watkins PJ, Costello JF. Diminished bronchial reactivity to cold air in diabetic patients with autonomic neuropathy. $\mathrm{Br} \mathrm{Med}$ J 1984;289:149-51.

4 Heaton RW, Guy RJC, Watkins PJ, Costello JF. Bronchial histamine reactivity in diabetic subjects with and without autonomic neuropathy [abstract]. Thorax 1985;40:217.

5 Rees PJ, Clark TJH. Assessment of antitussive effects by citric acid. Br J Dis Chest 1983;77:94-7.

6 Pounsford JC, Saunders KB. Diurnal variation and adaptation of the cough response to citric acid in normal subjects. Thorax 1985;40:657-61.

7 McKay JD, Page MMcB, Cambridge J, Watkins PJ. Diabetic autonomic neuropathy. The diagnostic value of heart rate monitoring. Diabetologia 1980;18:471-8.

8 Cotes JE. Lung function: principles and application in medicine. 4th ed. Oxford: Blackwell Scientific Publications, 1979.

9 Levin AB. A simple test for cardiac function based upon the heart rate changes induced by the Valsalva manoeuvre. Am J Cardiol 1966;18:90-9.

10 Pounsford JC, Birch MJ, Saunders KB. Effect of bronchodilators on the cough response to inhaled citric acid in normal and asthmatic subjects. Thorax 1985;40: 662-7.

11 Widdicombe JG. Respiratory reflexes from the trachea and bronchi of the cat. J Physiol 1954;123:55-70.

12 Widdicombe JG. Receptors in the trachea and bronchi of the cat. J Physiol 1954;123:71-104.

13 Mills JE, Sellick H, Widdicombe JG. Activity of lung irritant receptors in pulmonary microembolism, anaphylaxis and drug-induced bronchoconstriction. $J$ Physiol 1969;203:337-57.

14 Ewing DJ, Campbell IW, Clarke BF. The natural history of diabetic autonomic neuropathy. $Q J \mathrm{Med} 1980$; 49:95-108. 